\section{Indicator Crop Bioassays to Define Citrus Productivity in Sandy Soils}

\author{
Kirandeep K. Mann' ${ }^{1}$ and Arnold W. Schumann \\ Citrus Research and Education Center, University of Florida, 700 Experiment \\ Station Road, Lake Alfred, FL 33850
}

\author{
Thomas A. Obreza and Jerry B. Sartain \\ Soil and Water Science Department, University of Florida, McCarty Hall A, \\ Gainesville, FL 32611
}

Additional index words. soil variability, citrus, depth

\begin{abstract}
Citrus production in Florida is commonly affected by a high degree of spatial variability of soils. Therefore, this study developed rapid indicator crop bioassays to evaluate the relationships between indicator crops and citrus production at various soil depths. A citrus grove was divided into five productivity zones based on existing tree canopy volume using GIS software ("very poor," "poor," "medium," "good," and "very good"). Visual ratings of percentage cover were collected from each zone using a 1-m² quadrant. Six random soil samples were collected between the tree rows from each productivity zone at four depths ( $(0$ to 15,15 to 30,30 to 45 , and 45 to $60 \mathrm{~cm}$ ). Greenhouse bioassay experiments used sorghum and radish crops grown in soil sampled from four depths. Overhead photographs of potted radish plants were captured periodically with a SLR digital camera to calculate leaf area by image processing. Shoot weights, shoot length, root weights, and leaf nutrient concentrations were measured at harvest (56 and 21 days after germination for sorghum and radish, respectively). Germination, shoot length, and shoot weight of sorghum and radish were significantly affected by the productivity zone. Sorghum $(0$ to $30 \mathrm{~cm})$, radish $(0$ to 45 and 0 to $60 \mathrm{~cm})$ and weed cover were strongly correlated $(r \approx 0.50$ to $0.60 * * *)$ with citrus yield and canopy volume at the lower two depths. The strong relationships $(r>0.50 * * *)$ of sorghum and radish shoot weights and weed cover with soil properties at greater depths demonstrated the important role of cumulative root zone depth of $60 \mathrm{~cm}$ in differentiating citrus productivity. These results revealed that citrus production in poor areas of the grove was limited by the shallow depth of productive soil, and citrus productivity could be successfully mapped using indicator crop bioassays with soil samples taken at multiple depths.
\end{abstract}

The soils under Florida citrus production have very poor natural fertility. Furthermore, on some sandy soils, the problems of spatial variability in yield and soil properties are very common. The poor growth areas of a field have a much lighter soil color than surrounding productive areas. The presence of light-colored soils in the areas of low productivity indicates that these soils are devoid of coatings on sand particles, because an absence of coatings is indicated by light gray or white colors with Munsell chroma 2 or less and value 7 or greater (Harris et al., 1996). These amorphous coatings impart a high surface area to sand grains and are

\footnotetext{
Received for publication 10 May 2010. Accepted for publication 29 Sept. 2010

We acknowledge the support by the Florida Agricultural Experiment Station and the Hunt Brothers graduate fellowship. We thank Mosaic Co. for the use of their grove and the staff and students of the Citrus Research and Education Center (CREC) who assisted in this study.

Mention of trade names and commercial products is solely for the purpose of providing specific information and does not imply recommendation by the University of Florida or its cooperators.

${ }^{1}$ To whom reprint requests should be addressed; e-mailmannkk@ufl.edu.
} 15 and 15 to $30 \mathrm{~cm}$ (Mann et al. 2009) However, fertilizer recommendations in these groves rely on soil samples collected from the surface 15- to 20-cm layer (Obreza et al., 2008) and the vertical variability in soil properties is ignored.

Based on the horizontal and vertical variations in soil properties between the productivity zones, we hypothesized that shallowrooted crops will perform better in poor areas of a grove than the deep-rooted crops. The vertical variations in soil properties necessitate the need to develop a productivity index for citrus grove using soil samples of different depths. Because these sandy soils can be ameliorated to improve soil-waterplant relationships using organic and inorganic amendments, the potential efficacy of amendments can be tested rapidly using the plant bioassays in the greenhouse. Indicator crop bioassays have been successfully used to evaluate fertility or nutrient effects on crop growth (Ahlrichs et al., 1990; Obilo and Ogunyemi, 2005; Zebarth et al., 2005). For a bioassay to serve as a routine test, it should be simple and rapid to conduct. Sorghum (Sorghum bicolor L. Moench) belongs to the Poaceae family of monocots and is a rapidly growing crop. Sorghum has a fine and fibrous root system with an extremely large surface area and can produce an extensive fibrous root system as deep as 5 feet (Armah-Agyeman et al., 2002). Dry matter yield, nutrient concentrations, and total plant nutrient content of forage sorghum vary greatly under the conditions of variable soil fertility in Florida soils (Lilly and Gallaher, 1989) suggesting that sorghum does respond to variable soil conditions. Radish (Raphanus sativus L.) belongs to the family Brassicaceae of dicots, is a shallowrooted vegetable with a distinct taproot, and grows rapidly. Variable vegetable production in Florida sandy soils is also related to the variable soil conditions (Muchovej et al., 2005). Along with the mentioned reasons, the rapid growth characteristics of sorghum and radish also make them potential candidates to be used as indicator crops for quick bioassay experiments. Therefore, we selected these two crops (a monocot and a dicot) to evaluate their performance in the soil samples collected at different depth intervals from the citrus grove showing soil and tree growth variability. In addition to the indicator crops, weed occurrence in a field can also be used as an indicator of yield and soil quality (Suarez et al., 2001).

We hypothesized that bioassay experiments can be used to develop relationships of the indicator crops with citrus tree growth and yield, and these bioassay indicator crops can also help define the soil depth most limiting to citrus production in the variable citrus grove. Hence, the objectives of current investigations were to 1) calibrate a soil productivity index for citrus growth using indicator crop bioassays; and 2) determine the soil depth most influencing production in groves with variable tree growth.

\section{Materials and Methods}

\section{Study site}

A 10-ha commercial citrus grove (lat. $27.27259^{\circ} \mathrm{N}$, long. $81.52200^{\circ} \mathrm{W}$ ) located near Wauchula in Hardee County, FL, was selected to develop indicator crop bioassays and to evaluate the relationships between indicator crops and citrus tree growth and yield at various soil depths. This 19 -year-old grove was planted with a mixture of 'Hamlin' and 'Valencia' orange trees on mixed rootstocks. The experimental citrus grove was divided in Arcview developed by the Economic and 
Social Research Institute (ESRI, Redlands, CA.) into five productivity zones based on the ultrasonically measured tree canopy volume of citrus trees (Fig. 1) and these zones were independent of soil type. Number of productivity zones was five to relate citrus grove productivity with five classes of critical limits recommended for soil and tissue analysis of citrus (Obreza et al., 2008). These five productivity zones were named based on the variable tree canopy volumes and termed as "very poor" (canopy volume 0 to $1.84 \mathrm{~m}^{3}$ / row), "poor" (canopy volume 1.84 to $3.67 \mathrm{~m}^{3} /$ row), "medium" (canopy volume 3.67 to 5.51 $\mathrm{m}^{3} /$ row), "good" (canopy volume 5.51 to 7.34 $\mathrm{m}^{3} /$ row), and "very good" (canopy volume three soil series: excessively drained soil series St. Lucie (hyperthermic, uncoated, Typic Quartzipsamments), moderately well-drained soil series Tavares (hyperthermic, uncoated, Typic Quartzipsamments), and poorly to very poorly drained soil series Myakka (sandy, siliceous, hyperthermic, Aeric Alaquods) according to the Natural Resources Conservation Service (NRCS, County Soil Survey, 1999) (http://soils.usda.gov).

\section{Soil sampling}

Six random sites spanning the entire area of each productivity zone were selected. In July 2006, soil samples were collected between tree rows from these 30 sites at four depths ( 0 to 15,15 to 30,30 to 45 , and 45 to $60 \mathrm{~cm}$ ) resulting in a total of 120 soil samples. The samples were air-dried, passed through a 2-mm sieve, and used for greenhouse bioassay experiments. The bioassay experiments were set up in the greenhouse facilities of the Citrus Research and Education Center, University of Florida, Lake Alfred, FL. Average day/night temperature in the greenhouse was $36 / 21{ }^{\circ} \mathrm{C}$ and the relative humidity varied from $40 \%$ to $80 \%$.

\section{Productivity indices}

Sorghum as a productivity index of the citrus grove-Greenhouse Expt. 1. A greenhouse bioassay experiment with forage sorghum (Sorghum bicolor L. Moench) as the indicator crop was planned to compare the productivity potential of five zones at four depths in Fall 2006. The experimental units 7.34 to $9.18 \mathrm{~m}^{3} / \mathrm{row}$ ). The grove contained

were 1-L plastic pots arranged in a completely randomized design (CRD) with six replications. The pots were filled with $0.5 \mathrm{~kg}$ soil, brought to field capacity water content $(4 \%$ to $13 \%$ moisture at field capacity or at $10 \mathrm{kPa}$ in different soils), and weighed. Fertilizer was added in eight split applications at the total equivalent rate of $168 \mathrm{~N}-49 \mathrm{P}-93 \mathrm{~K} \mathrm{~kg} \cdot \mathrm{ha}^{-1}$ using ammonium nitrate, potassium dihydrogen phosphate, and potassium chloride stock solutions at weekly intervals. Ten sorghum seeds were planted in each pot and thinned to five plants at $10 \mathrm{~d}$ after planting. The soils were brought to their respective field capacity moisture content (4\% to $13 \%$ moisture at field capacity or at $10 \mathrm{kPa}$ in different soils) by weighing pots at weekly intervals. Germination percentage was recorded after $10 \mathrm{~d}$. The chlorophyll index was measured as average of five leaves (one leaf from each plant and five plants per pot) weekly using a SPAD502 chlorophyll meter (Minolta Corp., Ramsey, NJ). Shoot length was also measured weekly. Interveinal chlorosis symptoms on the leaves were rated using six classes with 0 as green and healthy, 1 as slightly yellow, 2 as onefourth of the leaves showing interveinal chlorosis, 3 as half of the leaves showing interveinal chlorosis, 4 as three-fourths of the leaves with interveinal chlorosis, and 5 as all the leaves showed severe interveinal chlorosis. At termination of the experiment, $56 \mathrm{~d}$ after planting, plants were harvested and separated into shoots and roots. Shoots and roots were washed, dried in a forced draft oven at $70{ }^{\circ} \mathrm{C}$ for 48 to $72 \mathrm{~h}$, and weighed. Shoot and root weights were expressed as $\mathrm{Mg} \cdot \mathrm{ha}^{-1}$. This was calculated using the shoot weight per unit soil weight in the pot and then converted to shoot weight for hectare furrow slice weight. Leaf samples for nutrient analysis were ground to pass a $0.38-\mathrm{mm}$ sieve. Leaf phosphorus, potassium, calcium, magnesium, sulfur, manganese, iron, copper, zinc, and boron concentrations were determined by inductively coupled plasma atomic emission spectroscopy with a method described by Isaac and Johnson (1985).

Radish as a productivity index of the citrus grove-Greenhouse Expt. 2. A greenhouse bioassay experiment in a CRD using radish (Raphanus sativa L., cv. Early Scarlet Globe) as the indicator crop was set up in Fall

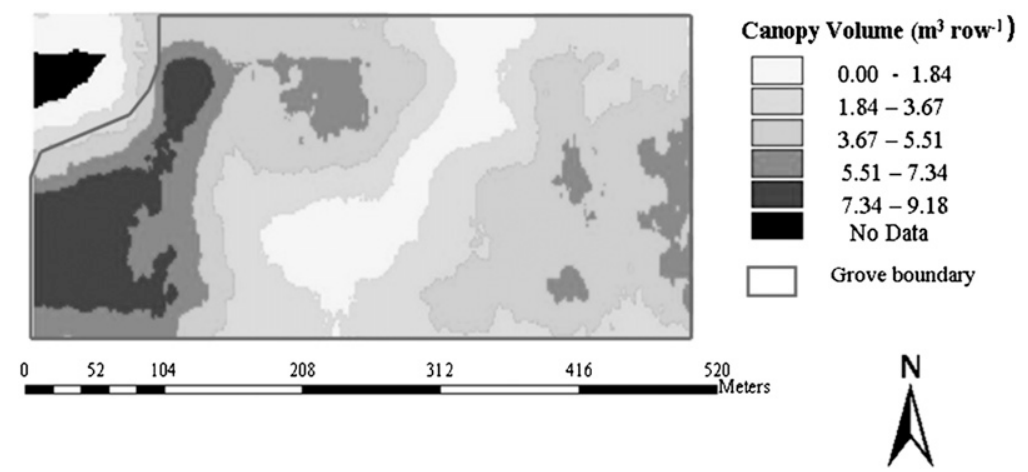

Fig. 1. Citrus grove divided into five productivity zones based on ultrasonically measured tree canopy volume.
2007 using 120 soil samples collected from 30 sites at four depths. Eight radish seeds were planted per pot and thinned to four plants $7 \mathrm{~d}$ after planting. To overcome any nutritional deficiencies as those observed in sorghum, a complete nutrient solution was applied to radish. The pots were fertilized in three split applications at weekly intervals to supply a total of $70 \mathrm{~kg} \mathrm{~N} / \mathrm{ha}$ with a soluble Peters 20-20-20 [N- $\left.\mathrm{P}_{2} \mathrm{O}_{5}-\mathrm{K}_{2} \mathrm{O}\right]$ commercial fertilizer blend (Scotts-Sierra Horticultural Products Co., Marysville, $\mathrm{OH}$ ) derived from urea, ammonium phosphate, potassium nitrate, potassium phosphate, magnesium sulfate, boric acid, copper EDTA, iron EDTA, manganese EDTA, sodium molybdate, and zinc EDTA. Germination percentage and chlorophyll greenness index measured with a SPAD-502 chlorophyll meter (Minolta Corp.) were recorded. Chlorophyll index readings were recorded only for the plants in the soils from 0 - to $15-\mathrm{cm}$ depth interval, because the radish leaves for the plants at lower three depths were too small to collect chlorophyll meter readings. Leaf area was measured for radish leaves using overhead photographs $0.3 \mathrm{~m}$ above the potted radish plants. Photographs were captured periodically with a SLR digital camera, and the leaf area was calculated by image processing software (Delphi 5.0; Borland, Austin, TX). After plant harvest $21 \mathrm{~d}$ after planting, shoot and root dry weights were recorded after processing as described for sorghum.

Weed cover as productivity index of citrus grove-Field data. Weed cover in the experimental citrus grove was recorded in July 2007. A $1-\mathrm{m}^{2}$ quadrant frame made of polyvinyl chloride plastic pipe was used to visually rate the percentage cover of weeds. The data were collected from 30 sites by selecting six random sites spanning the entire area of each zone. Photographs from $1.5 \mathrm{~m}$ above each site were also captured from five productivity zones. The major weed species in the citrus grove were bermuda grass, canary grass, horse weed, wild oat, common lamb quarters, and spurge.

\section{Data analysis}

Classical statistics analysis. All statistical analyses were performed with SAS statistical software (Statistical Analysis System Institute, 2003). Normality was tested both graphically as well as numerically using PROC univariate analysis. Homogeneity of variances was tested by plotting means and variances and by the chi square test. Germination was transformed using the arcsin transformation and the original data are presented in tables. Analysis of variance (Table 1) was performed and was partitioned into main effects of soil and depth and their interaction (soil*depth). To compare productivity zones at different depths, data were analyzed separately at each depth. Means were separated using the Tukey test at alpha $=0.05$. Growth curves for both sorghum and radish were plotted. Sorghum and radish growth parameters were calculated for four cumulative depths of 0 to 15,0 to 30 , 0 to 45 , and 0 to $60 \mathrm{~cm}$ for correlation analysis. 
Relationships between citrus yield/canopy volume and all the indicator crops were developed at each cumulative depth. Growth parameters of indicator crops were also correlated with soil properties at four cumulative depths using regression analysis.

Geostatistical analysis. Geostatistical analysis was performed using ArcView and ArcGIS (ESRI, Redlands, CA). Attribute tables of indicator crop growth parameters were joined to a spatial data table and the data were interpolated at non-sampled locations by Kriging to produce detailed maps.

\section{Results and Discussion}

The interaction of productivity zone and depth did not affect any growth parameter

Table 1. Effects of productivity zone and depth on sorghum and radish shoot weight $(n=6$ in each of five zones).

\begin{tabular}{lcccccc}
\hline & \multicolumn{7}{c}{ Productivity zone } \\
\cline { 2 - 4 } Depth $(\mathrm{cm})$ & Very poor & Poor & Medium & Good & Very good & Mean $(\text { depth })^{\mathrm{z}}$ \\
\hline \multirow{2}{*}{$0-15^{\mathrm{x}}$} & $11.1 \mathrm{NS}$ & $12.2 \mathrm{NS}$ & $14.2 \mathrm{NS}$ & $14.0 \mathrm{NS}$ & $12.4 \mathrm{NS}$ & $12.8^{\mathrm{A}}$ \\
$15-30$ & $9.9 \mathrm{NS}$ & $11.6 \mathrm{NS}$ & $11.6 \mathrm{NS}$ & $12.2 \mathrm{NS}$ & $12.3 \mathrm{NS}$ & $11.5^{\mathrm{A}}$ \\
$30-45$ & $8.5 \mathrm{NS}$ & $9.6 \mathrm{NS}$ & $9.1 \mathrm{NS}$ & $9.0 \mathrm{NS}$ & $5.1 \mathrm{NS}$ & $8.3^{\mathrm{B}}$ \\
$45-60$ & $7.6 \mathrm{NS}$ & $9.0 \mathrm{NS}$ & $8.6 \mathrm{NS}$ & $7.9 \mathrm{NS}$ & $4.7 \mathrm{NS}$ & $7.6^{\mathrm{B}}$ \\
Mean (zone) & $9.3^{\mathrm{ABC}}$ & $10.6^{\mathrm{AB}}$ & $10.9^{\mathrm{A}}$ & $10.8^{\mathrm{A}}$ & $8.6^{\mathrm{BC}}$ & 10.0 \\
Mean $(0-30 \mathrm{~cm})$ & $10.51^{\mathrm{B}}$ & $11.87^{\mathrm{AB}}$ & $12.92^{\mathrm{A}}$ & $13.12^{\mathrm{A}}$ & $12.37^{\mathrm{A}}$ & - \\
& & & & & \\
$0-15$ & $3.34 \mathrm{~b}$ & $4.55 \mathrm{a}$ & $4.63 \mathrm{a}$ & $5.05 \mathrm{a}$ & $3.35 \mathrm{~b}$ & $4.18^{\mathrm{A}}$ \\
$15-30$ & $2.25 \mathrm{NS}$ & $2.57 \mathrm{NS}$ & $2.92 \mathrm{NS}$ & $2.68 \mathrm{NS}$ & $2.97 \mathrm{NS}$ & $2.68^{\mathrm{B}}$ \\
$30-45$ & $1.84 \mathrm{~b}$ & $2.67 \mathrm{a}$ & $2.90 \mathrm{a}$ & $2.77 \mathrm{a}$ & $2.69 \mathrm{a}$ & $2.57^{\mathrm{B}}$ \\
$45-60$ & $1.81 \mathrm{c}$ & $2.29 \mathrm{bc}$ & $2.34 \mathrm{bc}$ & $3.19 \mathrm{a}$ & $2.76 \mathrm{ab}$ & $2.48^{\mathrm{B}}$ \\
Mean (zone) & $2.31^{\mathrm{B}}$ & $3.02^{\mathrm{A}}$ & $3.20^{\mathrm{A}}$ & $3.42^{\mathrm{A}}$ & $2.94^{\mathrm{A}}$ & 2.98 \\
\hline
\end{tabular}

${ }^{2}$ Within a column, means of four depths averaged across five productivity zones with same uppercase letter are not significantly different $(P>0.05)$ by the Tukey's honestly significant difference (HSD) test.

${ }^{y}$ Within a row, means of five productivity zones averaged across four depths with same uppercase letter are not significantly different $(P>0.05)$ by the Tukey's HSD test.

${ }^{x}$ Within a row, means of five productivity zones at each depth with same lowercase letter are not significantly different $(P>0.05)$ by the Tukey's HSD test.

Leaf area was calculated by image processing by capturing overhead photographs of potted radish plants. NS $=$ non-significant at $0.05 P$ level. of sorghum or radish. Sorghum germination, shoot length, and shoot weight were affected by productivity zone $(P<0.0001)$. Depth affected the shoot length $(P<0.0001)$, shoot weight $(P<0.0001)$, root weight $(P<0.001)$, and chlorophyll index $(P<0.0001)$. Productivity zone affected radish leaf area, shoot weight, chlorophyll index $(P<0.0001)$, and root weight $(P<0.05)$. The effect of depth was significant $(P<0.0001)$ for leaf area and shoot weight.

\section{Sorghum as a productivity index of citrus grove}

The germination percentages at 0 - to 60 $\mathrm{cm}$ depth ranged from $22 \%$ (very poor) to $45 \%$ (good) between the productivity zones $(P<0.0001)$. Sorghum shoot weight decreased with soil depth when averaged across the five productivity zones (Table 1). At specific depths, shoot lengths varied between productivity zones only at 30 to 45 and 0 to $60 \mathrm{~cm}$, showing the shortest shoot length $(0.33$ and $0.38 \mathrm{~m})$ in the best (very good) zone. Shoot weights also decreased with depth when averaged across the productivity zones as well as within each zone. Increase in shoot weight along the productivity gradient was more than $2 \mathrm{Mg} \cdot \mathrm{ha}^{-1}$ at $15-$ to $30-\mathrm{cm}$ depth. However, at 30- to 45- and 45- to 60$\mathrm{cm}$ depths, the very good productivity zone had the lowest shoot weights, and the shoot weights of the other four zones did not differ. The increase in shoot weights between (a)

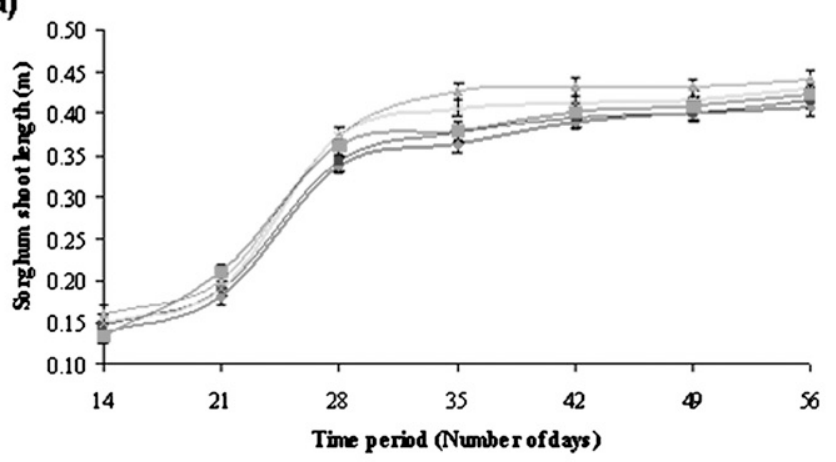

(c)

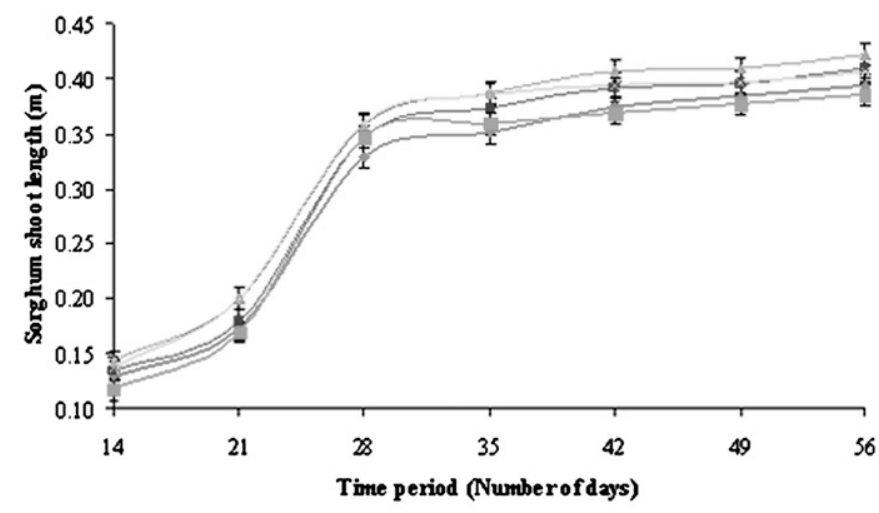

(b)

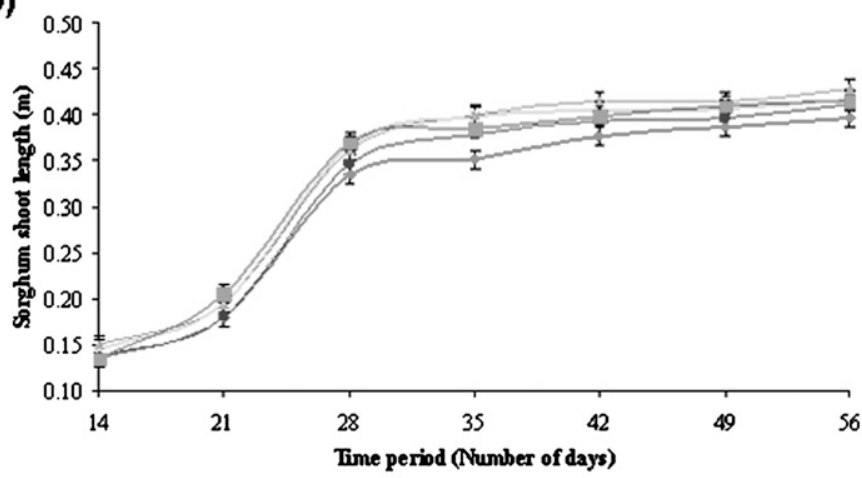

(d)

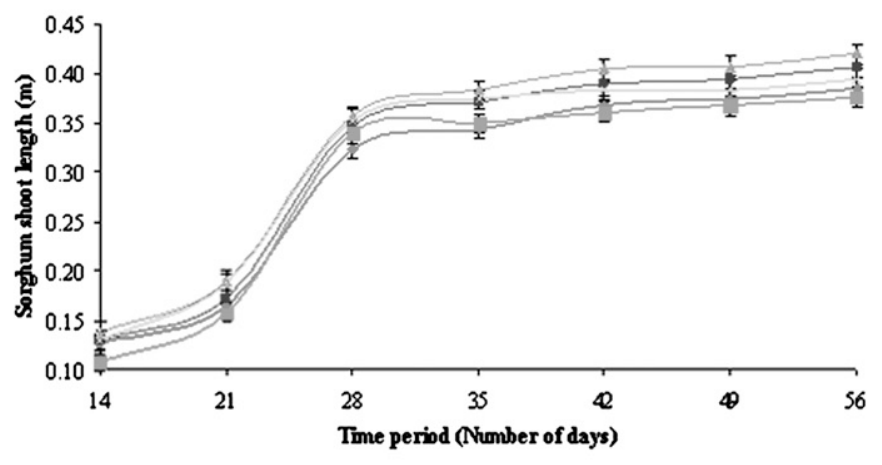

Fig. 2. Growth curves of sorghum at (A) 0- to 15-, (B) 0- to 30-, (C) 0- to 45-, and (D) 0 - to 60-cm depths. Each symbol represents a mean of six in each of five zones. 
productivity zones at 0 to $30 \mathrm{~cm}$ agrees with the variation in soil chemical and physical properties along the productivity gradient (Mann et al., 2009, 2010b). As a result of the poor performance of the very good productivity zone soils at the lower two depths, sorghum shoot weight was also compared at the cumulative 0 - to $30-\mathrm{cm}$ depth, where the best three zones (very good, good, and medium) had the highest shoot weights followed by the poor and very poor productivity zones. These results indicated that the very good zone restricted sorghum growth only at the lower two depth intervals.

Poor performance of the very good productivity zone at 30 - to $45-$ and $45-$ to $60-\mathrm{cm}$

Table 2. Effect of productivity zone on germination, chlorophyll index, and root weight of radish and weed cover ( $n=6$ in each of five zones).

\begin{tabular}{lcccc}
\hline Productivity & \multicolumn{4}{c}{ Radish growth parameter } \\
\cline { 2 - 5 } zone & Germination $\%^{\mathrm{y}}$ & Chlorophyll index & Root wt $\left(\mathrm{Mg} \cdot \mathrm{ha}^{\mathrm{D}}\right)$ & ${\text { Weed } \operatorname{cover}^{\mathrm{w}}(\%)}^{\mathrm{x}}$ \\
\hline Very poor & $27.5^{\mathrm{d}}$ & $33.8^{\mathrm{a}}$ & $0.079^{\mathrm{ab}}$ & $20^{\mathrm{c}}$ \\
Poor & $43.3^{\mathrm{c}}$ & $30.5^{\mathrm{b}}$ & $0.067^{\mathrm{b}}$ & $47^{\mathrm{b}}$ \\
Medium & $58.3^{\mathrm{ab}}$ & $27.8^{\mathrm{bc}}$ & $0.074^{\mathrm{ab}}$ & $63^{\mathrm{b}}$ \\
Good & $55.4^{\mathrm{bc}}$ & $25.2^{\mathrm{c}}$ & $0.082^{\mathrm{a}}$ & $87^{\mathrm{a}}$ \\
Very good & $69.2^{\mathrm{a}}$ & $25.5^{\mathrm{c}}$ & $0.073^{\mathrm{ab}}$ & $97^{\mathrm{a}}$ \\
\hline
\end{tabular}

${ }^{\mathrm{z}}$ For each productivity zone, within column, means with same letter are not significantly different $(P>$ $0.05)$ by the Tukey's honestly significant difference test.

${ }^{y}$ Germination was analyzed after transforming data using arcsin transformation, but original data are presented in the Table.

${ }^{\mathrm{x}}$ Chlorophyll index was measured using a SPAD chlorophyll meter.

${ }^{\mathrm{w}}$ Weed cover expressed as percent of groundcover was estimated using a $1-\mathrm{m}^{2}$ quadrant frame to visually rate the weed cover depths can be attributed to the occurrence of visible interveinal chlorosis symptoms, which could be the result of iron ( $\mathrm{Fe}$ ) and manganese Mn) deficiency. Soil-available Fe and $\mathrm{Mn}$ of $\mathrm{L}^{-1}$ and $0.5 \mathrm{mg}^{-1}$ at these two At lower depths ( 30 to 45 and 45 to $60 \mathrm{~cm}$ ), interveinal chlorosis ratings ranged from 2.8 2.9 for very poor and very good produczones, which were higher $(P=0.0008)$ the poor, medium, and good productivity zones (1.4 to 1.6). The concentration of leaf to $\left.10 \mathrm{mg} \cdot \mathrm{kg}^{-1}, P<0.0001\right)$ were also lowest in the very good productivity zone at these two depths. Interveinal chlorosis affected sorghum (a)

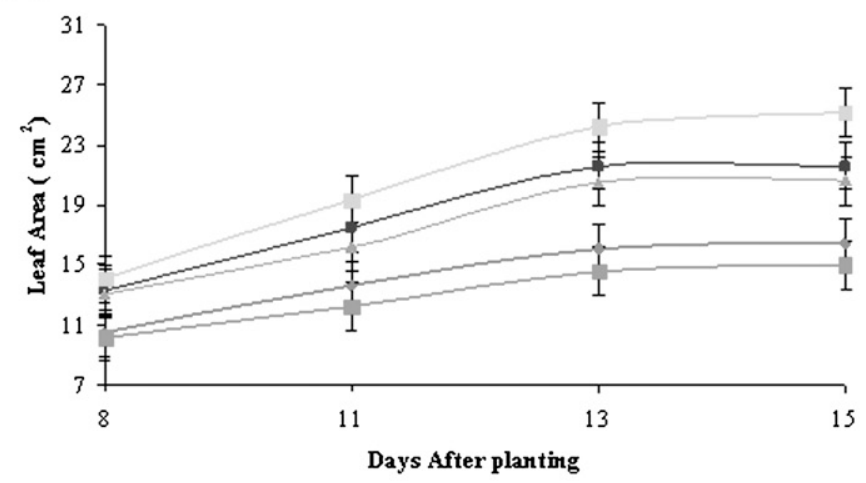

(c)

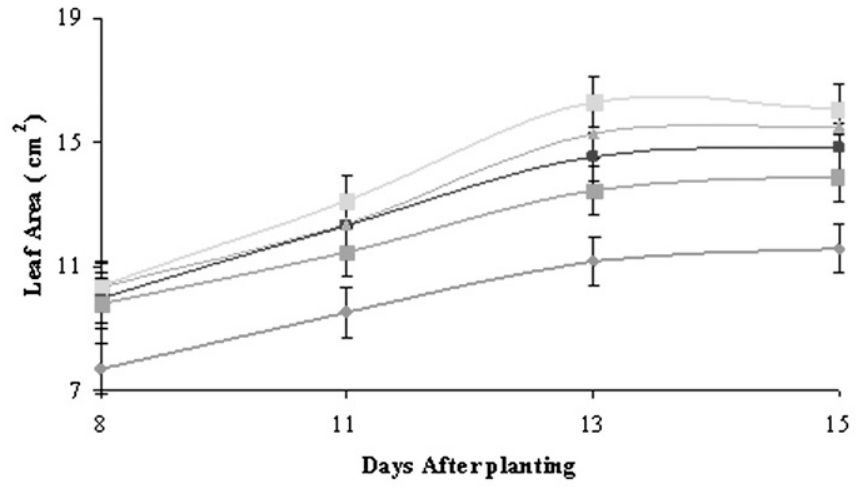

(b)

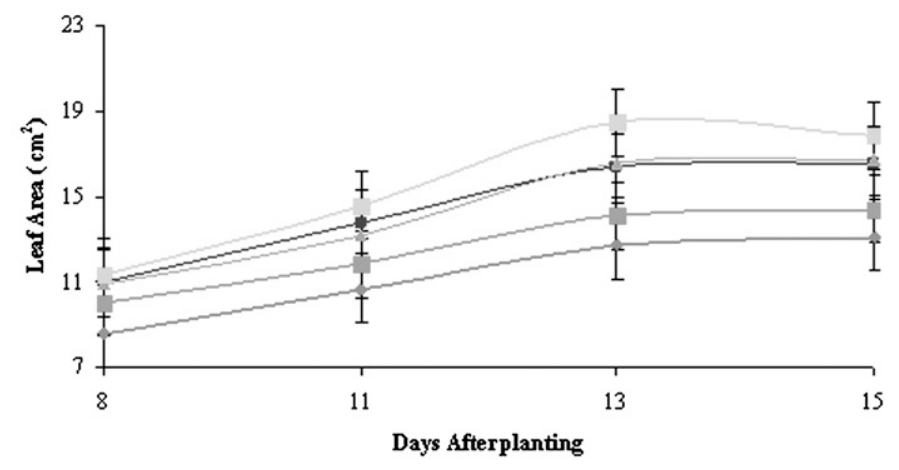

(d)

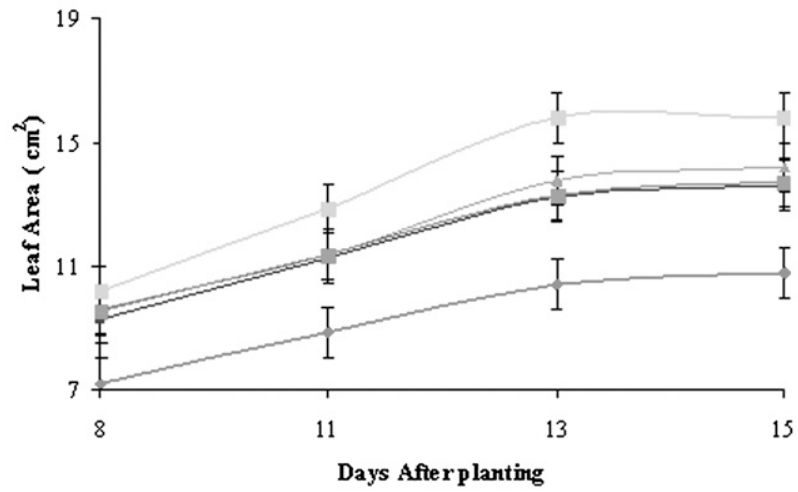

at the lower two depths. However, the variation in sorghum growth in the other four productivity zones followed the trend of gradient in canopy volume and productivity.

Productivity zone did not affect the chlorophyll index and root weight; however, they were affected by depth. Chlorophyll index (26.9 to 22.2, $P<0.05$ ) and root weight (15.8 to $\left.12.1 \mathrm{Mg} \cdot \mathrm{ha}^{-1}, P<0.05\right)$ decreased continuously with depth. Growth curves of sorghum shoot length (Fig. 2) showed that the differences between the productivity zones appeared at $28 \mathrm{~d}$ of growth. The very good productivity zone had higher shoot lengths at 0 - to 15 - and 0 - to $30-\mathrm{cm}$ depths but lower at 0 - to $45-$ and 0 - to $60-\mathrm{cm}$ depths. The very poor zone had the lowest shoot lengths at 0 to $30 \mathrm{~cm}$, but at 0 to 45 and 0 to $60 \mathrm{~cm}$, very poor and very good zones showed a similar pattern after $35 \mathrm{~d}$ when the effect of interveinal chlorosis started to overcome the difference of productivity.

\section{Radish as a productivity index of citrus grove}

Radish shoot weight decreased continuously with depth, showing maximum productivity in the surface $15-\mathrm{cm}$ layer (Table 1). For specific depths, the differences between productivity zones were pronounced at greater depths, suggesting that citrus yield in poor areas of the grove was limited by the shallow soil. At the mean depth of 0 to $60 \mathrm{~cm}$, shoot weight increased along the productivity 
gradient with the highest values in the very good, good, medium, and poor zones followed by the very poor productivity zone.

Effect of productivity zone on germination, chlorophyll index, and root weight of radish showed that germination increased by more than twofold along the productivity gradient (Table 2). Chlorophyll index decreased with productivity possibly as a result of the dilution effect in the higher productivity zones because they had more shoot growth. Root weights were higher in the good as compared with the poor productivity zone. Results of radish growth were very similar to sorghum growth between the productivity zones, except that radish growth discriminated the productivity zones at greater depths, whereas this was not the case in sorghum as a result of severe interveinal chlorosis at lower two depths. This difference was undoubtedly because radish was supplied with the complete nutrient solution, whereas only major nutrients were supplied in sorghum.

Growth curves of the radish leaf area showed that the differences between five productivity zones started appearing at later growth stages (Fig. 3). Some decrease in leaf area at $15 \mathrm{~d}$ for the productivity zones with previously larger leaf areas was the result of overlapping of the leaves. Comparing different depths, the very poor productivity zone was differentiated from the upper four pro- ductivity zones at the lower two soil depths, and at 0 to $15 \mathrm{~cm}$, this zone had higher leaf area than the very good productivity zone. These observations also suggested that citrus production was not limited by variations in soil properties at the surface layer. However, at the lower two depths, differences between five productivity zones appeared at the initial growth stages. Although the very good productivity zone could not explain sorghum growth at all depth intervals was related to severe chlorosis, the differences in sorghum and radish growth corresponded with horizontal and vertical variation in productivity within the grove. Horizontal and vertical variation of soil nutrient status is widely correlated with variability in yield (Aggelopoulou et al., 2007; Cox and Gerard, 2007).

\section{Weed cover as a productivity index of citrus grove}

Effect of productivity zone on weed cover (Table 2) showed its continuous increase along the productivity gradient. Weed cover ranged from $20 \%$ to $97 \%$ in different productivity zones. These results were in agreement with the observed weed cover in five productivity zones of the citrus within the grove. The results revealed that weed cover in a field can also be used as an indicator of soil fertility and productivity (Murage et al., 2000).
Relationship of productivity indices with citrus production and soil properties

Spatial patterns of sorghum shoot weight at 0 - to $30-\mathrm{cm}$ depth, radish shoot weight at 0 - to 60-cm depth, and weed cover (Fig. 4) had a very similar pattern as that observed for citrus tree canopy volume (Fig. 1). The variation in crop growth along the productivity gradient were $1.5 \times$ for sorghum shoot weight, $\approx 2 \times$ for radish shoot weight, and $5 \times$ for the weed cover. These spatial patterns of three productivity indices also appear similar to the variable patterns of yield and normalized difference vegetation index (NDVI) (Mann et al., 2010a). Shoot weights of sorghum and radish and weed cover were low in the center of the grove but had higher growth in the eastern and western sides of the grove. Similar were the patterns of yield, canopy volume, and NDVI.

Relationships of sorghum and radish shoot weights with citrus production at four cumulative depths (Table 3 ) revealed significant positive relationships of shoot weight at the 0 - to 30-cm depth for both yield $\left(r=0.486^{*}\right)$ and canopy volume $\left(r=0.427^{*}\right)$. Sorghum growth parameters were negatively correlated with citrus production at 30 - to 45 - and 45 - to 60 -cm depths, because the very good zone had the lowest sorghum growth at these two depths as a result of chlorosis. Correlation analysis between radish and citrus growth parameters (a)

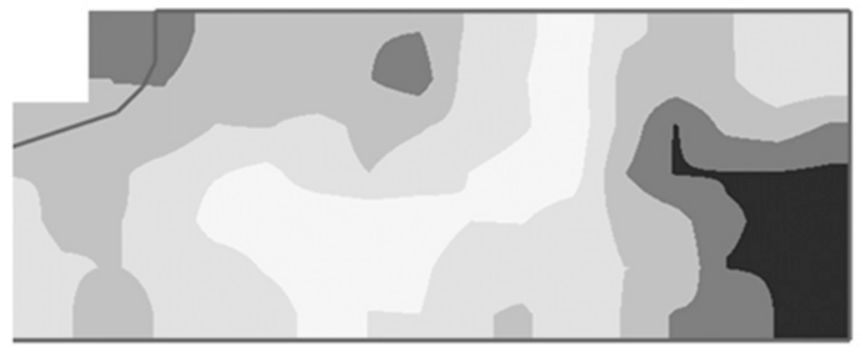

(b)

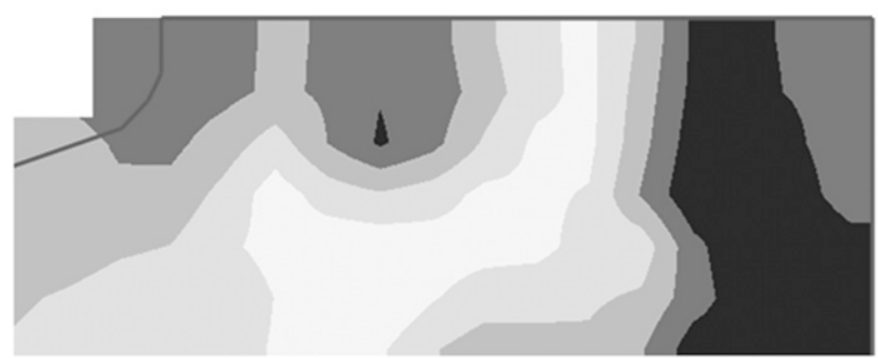

(c)

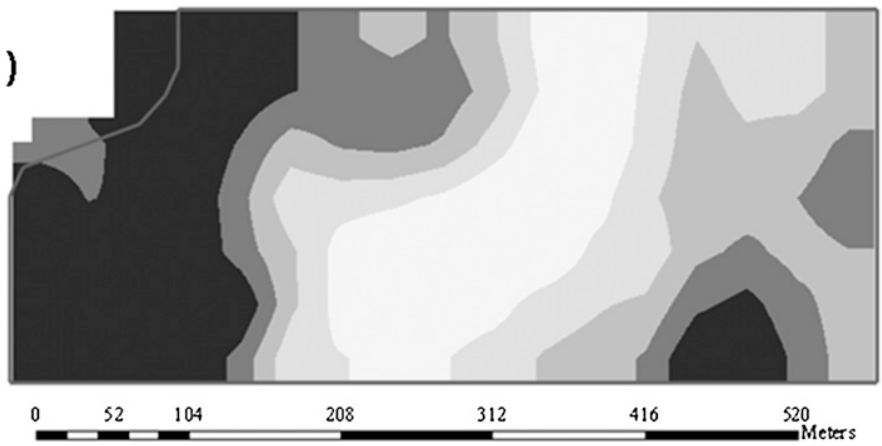

Sorghum shoot weight (Mg ha-1)

$10.2 \cdot 11.2$

$11.2-12.3$

$12.2-13.2$

13. $2 \cdot 14.2$

$14.2-15.2$

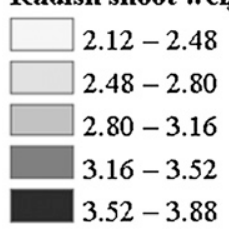

Weed cover (\%)
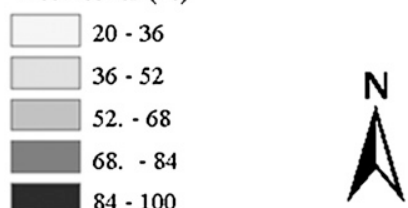

Grove boundary

Fig. 4. Interpolated maps of (A) sorghum shoot weight at 0 - to 30-cm depth, (B) radish shoot weight at 0 - to 60 -cm depth, and (C) weed cover from the data of 30 sites ( $\mathrm{n}=6$ in each of five zones). 
also showed positive relationships of radish leaf area and shoot weight with citrus yield and canopy volume. These relationships became stronger and significant at increased cumulative depths with the highest $r$ value ( $r=0.577^{* * *}$ for yield and $r=0.459^{*}$ for canopy volume) at 0 - to $60-\mathrm{cm}$ depth. Weed cover was also strongly positively correlated with yield $\left(r=0.85^{* * *}\right)$ and canopy volume $(r=0.92 * * *)$.

Relationships of indicator crops with soil properties (Table 4) revealed a strong dependency of crop growth on soil chemical and physical properties. Sorghum shoot weight, radish shoot weight, and weed cover had significant positive relationships with organic matter, cation exchange capacity (CEC), Mehlich I-extractable phosphorus $(\mathrm{P})$, potassium $(\mathrm{K})$, and calcium, oxalate-extractable aluminum (Al), and volumetric water content at permanent wilting point (PWP). Organic matter is a valuable component for sandy soils under Florida citrus production and it plays a key role in the productivity potential by enhancing nutrient availability, improving soil structure, and increasing water-holding capacity of the soils. Organic matter affects CEC significantly owing to its large specific surface area along with the diversity of cation sub- stitution sites (Ersahin et al., 2006). The correlations were negative with soil lightness $\left(\mathrm{L}^{*}\right)$, total sand, coarse sand, and medium sand fractions. Soil color is a good indicator of various soil properties, including organic matter (Galvao et al., 2001), Fe content (Rossel et al., 2008), and soil water content (Galvao et al., 1997).

These relationships for sorghum increased with increasing cumulative depth up to 0 to $30 \mathrm{~cm}$, but increases in $r$ values occurred up to 0 - to $60-\mathrm{cm}$ depth for radish and weed cover. Similar relationships of citrus fruit production and tree canopy volume with soil properties at various depths were observed by Mann et al. (2009). The high $r$ values for organic matter, CEC, Mehlich I extractable P, and K, oxalateextractable $\mathrm{Al}$, and volumetric water content at PWP emphasized the important role of organic matter, soil-available nutrients, coatings on sand grains, and water retention in affecting growth of various indicator crops and in explaining the soil productivity of the citrus grove. The relationships of three indicator crops with citrus production and soil properties revealed that much of the variation in the soil productivity of citrus groves at different depths can be explained using indicator crop bioassays. Sorghum could ex-

Table 3. Correlation coefficients of shoot weight of sorghum and radish with citrus yield and canopy volume.

\begin{tabular}{lclc}
\hline & & \multicolumn{2}{c}{ Citrus growth parameters } \\
\cline { 3 - 4 } Sorghum growth parameters & Cumulative depth $(\mathrm{cm})$ & \multicolumn{1}{c}{ Yield } & Canopy volume \\
\hline Sorghum shoot weight & $0-15$ & $0.275 \mathrm{NS}^{\mathrm{z}}$ & $0.297^{\mathrm{NS}}$ \\
& $0-30$ & $0.486^{*}$ & $0.427^{*}$ \\
& $0-45$ & $0.213 \mathrm{NS}$ & $0.051 \mathrm{NS}$ \\
Radish shoot weight & $0-60$ & $0.118 \mathrm{NS}$ & $-0.112 \mathrm{NS}$ \\
& $0-15$ & $0.321 \mathrm{NS}$ & $0.077 \mathrm{NS}$ \\
& $0-30$ & $0.447^{*}$ & $0.241 \mathrm{NS}$ \\
& $0-45$ & $0.489^{* *}$ & $0.316 \mathrm{NS}$ \\
\hline
\end{tabular}

${ }^{\mathrm{z}_{\mathrm{NS}}}=$ Non-significant at $0.05 P$ level, $*{ }^{* *},{ }^{* * *}$ significant at the $0.05,0.01$, and $0.001 P$ level, respectively, $\mathrm{n}=30$. plain productivity up to the 0 - to 30 -cm depth, in which its growth increased with the productivity gradient. Radish seedlings and weeds could better explain the productivity at the 0 to $60-\mathrm{cm}$ depth, demonstrating the important role of cumulative root zone depth of $60 \mathrm{~cm}$ in differentiating the productivity of the citrus grove.

While correlating sorghum, radish, and weed cover used as indices of citrus grove productivity with each other, the correlation coefficients indicated that sorghum shoot weights were significantly positively correlated with radish at 0 - to $15-\mathrm{cm}\left(r=0.424^{*}\right)$ and with weeds at 0 - to $15-\mathrm{cm}\left(r=0.377^{*}\right)$ and 15 - to $30-\mathrm{cm}\left(r=0.386^{*}\right)$ depths. Radish was significantly positively correlated with weed cover at the lower three depths $(r=$ $0.372 *$ to $0.533 * *)$.

\section{Conclusions}

Our purpose was to evaluate the crop performance at soil samples collected from different depths. Based on the vertical variations in soil properties, we hypothesized that the poor citrus tree growth in the very poor productivity zone can be the result of low organic matter, CEC, nutrient status, and water retention at the lower soil depths. Sorghum and radish as bioindicator crops responded to most soil differences and showed variability of potential citrus grove productivity, suggesting that the indicator crops could be useful for identifying and predicting limitations to production that are not easily measured by standard laboratory chemical and physical analysis. Second, the relationships among indicator crops, citrus production, and soil properties demonstrated the role of cumulative root zone depth of $60 \mathrm{~cm}$ in explaining the citrus grove productivity. Citrus yield in poor areas of the grove was limited by the shallow depth of productive soil. Soil productivity potential

Table 4. Correlation coefficients of sorghum and radish shoot weights and weed cover with selected soil properties at four depths.

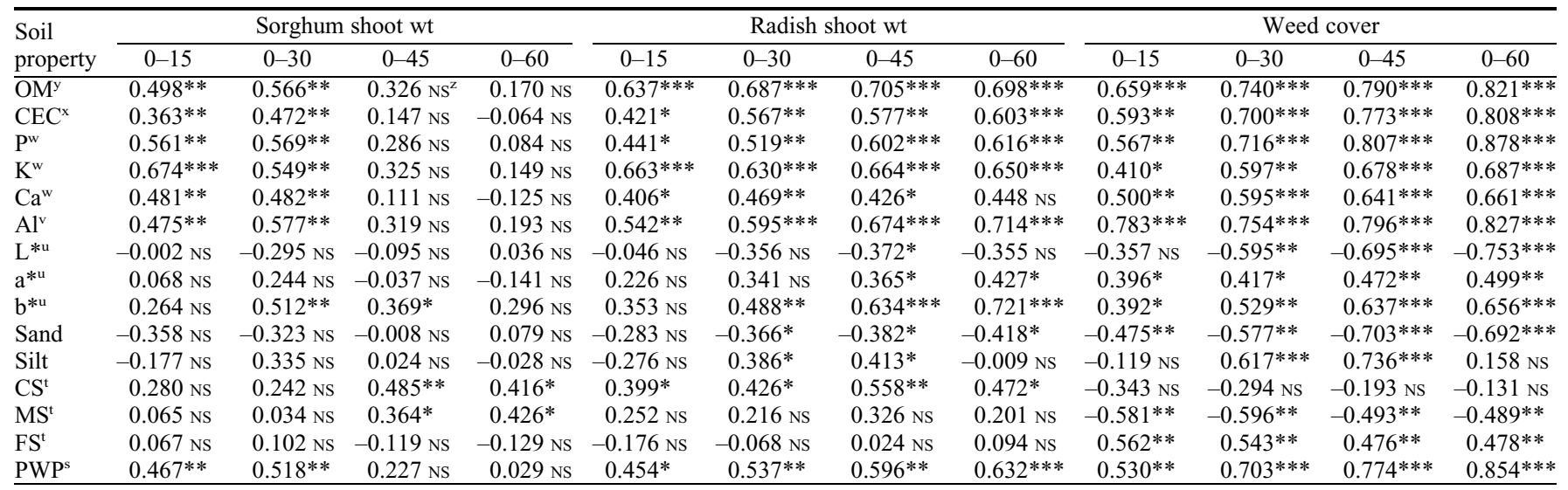

${ }_{\mathrm{N}} \mathrm{NS}=$ Non-significant at the $0.05 P$ level and $*, * *, * * *$ significant at $P<0.05,0.01$, and 0.001 , respectively, $\mathrm{n}=30$.

${ }^{\mathrm{y}}$ Organic matter.

${ }^{\mathrm{x}}$ Cation exchange capacity.

"Mehlich I-extractable nutrients.

voxalate-extractable nutrients.

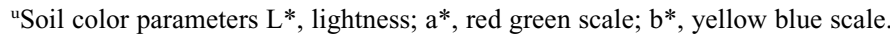

'Sand size fractions, coarse sand (CS); medium sand (MS); fine sand (FS).

${ }^{\mathrm{s}}$ Volumetric water contents at permanent wilting point. 
of the citrus could be successfully mapped using indicator crop bioassays with soil samples taken at multiple depths. Topsoil sampling alone, as commonly practiced, proved to be unsuitable for defining the variable citrus productivity of these soils.

\section{Literature Cited}

Aggelopoulou, K.D., D. Pateras, and S. Fountas. 2007. Soil spatial variability in small Greek apple orchards, p. 71-78. Conference information: Precision agriculture. Papers presented at the 6th European Conference on Precision Agriculture, Skiathos, Greece, 3-6 June 2007.

Ahlrichs, J.L., M.C. Karr, V.C. Baligar, and R.J. Wright. 1990. Rapid bioassay of aluminium toxicity in soil. Plant Soil 122:279-285.

Armah-Agyeman, G., J. Loiland, R. Karow, W.A. Payne, C. Trostle, and B. Bean. 2002. Grain sorghum. Dry land cropping systems. EM 8794.

Cox, M.S. and R.D. Gerard. 2007. Soil management zone determination by yield stability analysis and classification. Agron. J. 99:1357-1365.

Ersahin, S., H. Gunal, T. Kutlu, B. Yetgin, and S. Coban. 2006. Estimating specific surface area and cation exchange capacity in soils using fractal dimension of particle-size distribution. Geoderma 136:588-597.

Galvao, L.S., M.A. Pizarro, and J.C.N. Epiphanio. 2001. Variations in reflectance of tropical soils: Spectral-chemical composition relationships from AVIRIS data. Remote Sens. Environ. 75: 245-255.

Galvao, L.S., I. Vitorello, and A.R. Formaggio. 1997. Relationships of spectral reflectance and color among surface and subsurface horizons of tropical soil profiles. Remote Sens. Environ. 61:24-33.

Harris, W., R. Rhue, G. Kidder, R. Brown, and R. Littell. 1996. Phosphorus retention as related to morphology of sandy coastal plain soil materials. Soil Sci. Soc. Amer. J. 60:1513-1521.

Isaac, R.A. and W.C. Johnson. 1985. Elemental analysis of plant tissue by plasma emission spectroscopy: Collaborative study. JAOAC 68 : 499-505.

Lilly, D. and R. Gallaher. 1989. Forage sorghum growth and nutrition as affected by soil variability. Agron. Res. Report AY-89-09. Agron. Depart. Univ. of Fla. Inst. of Food and Agric. Sci., Gainesville, FL.

Mann, K.K., A.W. Schumann, and T.A. Obreza. 2009. Assessment of soil variability and its effect on citrus production: A statistical approach. Proc. Fla. State Hort. Soc. 122:51-60.

Mann, K.K., A.W. Schumann, and T.A. Obreza. 2010a. Delineating productivity zones in a citrus grove using citrus production, tree growth and temporally stable soil data. Precis. Agric. doi: 10.1007/s11119-010-9189-y.

Mann, K.K., A.W. Schumann, T.A. Obreza, W.G. Harris, and S. Shukla. 2010b. Spatial variability of soil physical properties affecting Florida citrus production. Soil Sci. 175:487-499.

Muchovej, R.M., E.A. Hanlon, M. Ozores-Hampton, F.M. Roka, S. Shukla, H. Yamataki, and K Cushman. 2005. Management of soil and water for vegetable production in southwest Florida Fla. Coop. Ext. Serv. SL233. 5 Aug. 2009. <http:// www.edis.ifas.ufl.edu/SS452>. Univ. of Fla. Inst. of Food and Agric. Sci., Gainesville, FL.
Murage, E.W., N.K. Karanja, P.C. Smithson, and P.L. Woomer. 2000. Diagnostic indicators of soil quality in productive and non-productive smallholders' fields of Kenya's Central Highlands. Agr. Ecosyst. Environ. 79:1-8.

Natural Resources Conservation Service, County Soil Survey. 1999. Official soil series descriptions (OSD) with series extent mapping capabilities. USDA. 29 Oct. 2010. <http://soils.usda. gov/technical/classification/osd>.

Obilo, O. and S. Ogunyemi. 2005. The use of maize as an indicator crop and in the reclamation of farm land laden with heavy metals as a result of crude oil pollution. Discov. Innov. 17:180-185.

Obreza, T.A., M. Zekri, and E.W. Hanlon. 2008. Soil and leaf tissue testing. 24-32. In: Obreza, T.A. and K.L. Morgan (eds.). Nutrition of Florida citrus trees. 2nd Ed. Fla. Coop. Ext. Serv. SL253. 16 Feb. 2009. <http://www.edis ifas.ufl.edu/SS478 $>$. Univ. of Fla. Inst. of Food and Agric. Sci., Gainesville, FL.

Rossel, R.A.V., Y. Fouad, and C. Walter. 2008. Using a digital camera to measure soil organic carbon and iron contents. Biosystems Eng. 100:149-159.

Statistical Analysis System Institute. 2003. SAS STAT Guide for personal computers. Version 9.1. SAS Inst. Inc., Cary, NC.

Suarez, S.A., E.B. De la Fuente, C.M. Ghersa, and R.C.J. Leon. 2001. Weed community as an indicator of summer crop yield and site quality. Agron. J. 93:524-530.

Zebarth, B., Y. Leclerc, G. Moreau, J. Sanderson, W. Arsenault, E. Botha, and G. Wang-Pruski. 2005. Estimation of soil nitrogen supply in potato fields using a plant bioassay approach Can. J. Soil Sci. 85:377-386. 